\title{
A kábítószer-bǘnözés aktuális kérdései nemzetközi kitekintésben
}

\section{NAGY Ivett ${ }^{1}$}

\begin{abstract}
A kábítószer-bünözés egyik fontos jellemzője, hogy nincsen sértettje a büncselekményeknek, és ezzel még inkább megnehezül a hatóságok munkája. Az Európai Unió más tagállamaiban is ezzel a kihívással kell szembenéznie a nyomozó hatóságoknak, így arra fókuszáltam, hogy milyen lehetőségek állnak a tagállamok rendelkezésére, hogy eredményes legyen a nyomozásuk. A hangsúlyt a nemzetközi együttmúködésre, rendörségi információcserére, múveleti együttmúködésre, valamint a szervezett bünözés elleni küzdelemre helyeztem. A kutatásom során interjúkat készítettem az osztrák társhatóságokkal, kutattam az Europol szerepét (kérdőives kutatás), majd az eddig feltárt eredmények tükrében, az amerikai szövetségi ügynökségekkel, továbbá az Egyesült Nemzetek Szervezete Kábítószer-ellenőrzési és Bünmegelözési Hivatalával is felvettem a kapcsolatot. Célom, hogy a megállapított eredményekkel a gyakorlatban alkalmazható, a szakma számára releváns megoldásokkal szolgáljak.
\end{abstract}

Kulcsszavak: kábítószer, nemzetközi, nyomozás

\section{Bevezetés}

A kábítószer-búnözés vizsgálatához elengedhetetlen a szervezett bűnözés alapjainak megismerése, hiszen a szervezett bűnözés egyik legnagyobb részét a kábítószer-bűncselekmények képezik. A szervezett bűnözés egyik legfontosabb jellemzője a nemzetközi jelleg, ezért ez még nagyobb kihívást jelent a nyomozó hatóságok számára minden országban, hiszen a nyomozások felderítéséhez elképzelhető, hogy több országot érintő szervezeti hálót kell figyelembe venni. Eddigi kutatásaim során, amely kezdetben Magyarországon, határainkon belül folyt, tapasztaltam, hogy nemzetközi kutatás nélkül nem kaphatok reprezentatív képet.

Több hipotézist is felállítottam, amelyekre az igazi választ a teljes kutatás végén kaphatom meg. Így azokra a kiemelkedően fontos szegmensekre helyeztem a hangsúlyt, amelyek által érdemi következtetéseket kapunk. Ilyen terület például a rend-

\footnotetext{
Nagy Ivett r. főhadnagy főnyomozó, Budapesti Rendőr-főkapitányság VII. kerületi Rendőrkapitányság Bünügyi Osztály Gazdaságvédelmi Alosztály; doktori hallgató, Nemzeti Közszolgálati Egyetem Rendészettudományi Doktori Iskola. Ivett Nagy Chief Police Inspector, Economic Protection Subdivision Criminal Department 7th District Police Headquarters, Budapest Police Headquarters; PhD student, University of Public Service Doctoral School of Police Sciences and Law Enforcement.

E-mail: Nagy.Ivett@uni-nke.hu, ORCID: https://orcid.org/0000-0001-7195-7000
} 
őrségi információcsere, a nemzetközi bűnügyi együttműködés, a szervezett bủnözés elleni küzdelem.

Kutatásom során interjúkat készítettem, illetve strukturált kérdőíves felmérést végeztem. Az interjúkészítés során az osztrák társhatóságokkal, amerikai szövetségi ügynökségekkel és az Egyesült Nemzetek Szervezete Kábítószer-ellenőrzési és Bűnmegelőzési Hivatalával vettem fel a kapcsolatot. A kérdőíves kutatást pedig az Europolnál dolgozó egyes munkatársakkal készítettem. A cikkben kitekintést teszek arra vonatkozóan, hogy a kábítószer-fogyasztás hogyan jelenik meg Ausztriában, illetve vannak-e eltérések a magyar helyzetképhez képest.

\section{A szervezett bünözés elleni küzdelem}

Nem csak hazánkban, de a világ minden pontján fel kell vennie a küzdelmet a szervezett bűnözés ellen a hatóságoknak, különböző hivataloknak. A szervezett bűnözés több száz éve jelen van, ám annak egyes jellemzői folyamatos változásban vannak. A Rendészettudományi szaklexikon szerint a szervezett bűnözés „az összbűnözés alrendszere, különös szintű jelenségcsoportja. Elkövetői valamely bűnszervezet tagjaként, ill. vezetőjeként a foglalkozásszerűen végzett egzisztenciateremtő tevékenységet tagolt munkamegosztás és magas fokú konspiráció mellett valósítják meg." A fogalomban megjelenő egyes fogalmi elemek is jól tükrözik, hogy a nyomozó hatóságoknak kellően felkészültnek kell lenniük a szervezett bűnözői csoportok elleni küzdelemben. Az egyes elkövetési magatartások rohamos változása is megnehezíti a küzdelmet. Jellemzően az ilyen bűncselekményeknél, mint a kábítószer-bűncselekmény is, nincs sértettje az ügynek, nincs, aki feljelentést tegyen, nincs, aki vagyoni kárt „követeljen”, továbbá mint már említettem, a legtöbb esetben több országot érintő büncselekményekről beszélünk. Gyakran olvashatjuk úgy is már, hogy súlyos és szervezett bűnözés, ami még inkább hangsúlyozza a fenyegetettséget. Néhány példát említve a kábítószer-bủncselekményen kívül, ilyen a terrorizmus, a pénzmosás, a pénzhamisítás vagy emberkereskedelem. Nehezítő tényező továbbá az internet megjelenése, hisz az online térben elkövetett bűncselekmények megelőzése, felderítése és bizonyítása számos pontban kihívást támaszt a hatóságok számára. A rendvédelmi szervek és a titkosszolgálatok titkos információgyưjtő tevékenysége, amely a bűnöző szervezetek tevékenységének megismerésére, azok bomlasztására irányul az Európai Unióban széles körben elfogadott és alkalmazott tevékenységgé vált. ${ }^{3} \mathrm{Az}$ államok felismerték azt, hogy együtt hatékonyabban lehet fellépni a szervezett bűnözés ellen. Az Európai Unió 2010 óta a tagállamok részvételével együtt közösen küzd a szervezett bűnözés ellen, létrejött az EMPACT platform. ${ }^{4}$ „Az EMPACT egy olyan ad hoc

\footnotetext{
Boda József (szerk.): Rendészettudományi szaklexikon. Budapest, Dialóg Campus, 2019. 535.

Nyeste Péter: A bűnügyi hírszerzés. Magyar Rendészet, 12. (2012), 4. 28.

European Multidisciplinary Platform against Criminal Threats - Európai Multidiszciplináris Platform a Búnügyi Fenyegetettség Ellen.
} 
menedzsment környezet, amely azért fejleszt ki egyes cselekvéseket, hogy biztosítsa az előre meghatározott célok elérését. A tagállamok, az EU ügynökségei és intézményei, a harmadik államok, valamint az állami és magán szervezetek olyan strukturált multidiszciplináris együttmúködési platformja, amely a prioritásként meghatározott súlyos és szervezett nemzetközi bűncselekmények ellen küzd." Így, ezáltal évről évre olyan stratégiai prioritási pontokat határoznak meg, amelyek elősegítik a kommunikációt, az együttmúködést, a tájékozódást. A súlyos és szervezett bűnözés helyzetével az Europol által kiadott úgynevezett SOCTA, ${ }^{6}$ azaz súlyos és szervezett bűnözés általi fenyegetettség értékelés foglalkozik négyéves időtávlatokban gondolkodva előre, évenkénti frissítéssekkel. A 2013-ban készült elemzés szerint, már akkor körülbelül 3600 szervezett bűnözői csoport működött az Európai Unión belül, akik már a tevékenységeket felosztják egymás között, ezáltal biztosítják részben a magas fokú konspirációt.7 A 2013-as értékelést követően, a 2017-ben kiadott elemzésben már 5000 ilyen csoport müködéséről számolnak be. Az előbbi elemzési és intézkedési termékek a szervezett bűnözés elleni küzdelem stratégiai, illetve a végrehajtási intézkedések tervezéséhez számítanak jó alapnak. Ezeken kívül a szervezett bűnözés elleni fellépésnek még számos más eszköze is van, de ezek részletes elemzésétől eltekintek a terjedelmi korlátok miatt.

\section{Kábítószer-bünözés}

\subsection{Europol}

Az Europolról, azaz a Bűnüldözési Együttműködés Európai Uniós Ügynökségéről, annak szervezetéről, múködéséről már számos tanulmány született. A legfontosabb hangsúlyozni azt, hogy önálló nyomozati jogkörrel nem rendelkezik. A Rendészettudományi szaklexikonban összefoglalóan megtalálható, hogy az Europol milyen tevékenységet végez. A szaklexikon szerint helyszíni támogatást nyújt különböző bűnüldözési műveletekhez, továbbá információs platformként is szolgál, és olyan központi szerepet tölt be, amely a bűnüldözési szakismeretekkel foglalkozik. ${ }^{8}$ Tehát az Europol segítségével lehetőség nyílik az Európai Unió tagállamainak közös kommunikációra, például a létrehozott közös nyomozócsoportok megbeszéléseinek lebonyolítását vállalja, továbbá technikai eszközöket biztosít az egyes tagállamoknak például egy kábítószer-laboratórium felszámolásához, biztosítja szakértők, úgynevezett specialisták segítségével a nagyobb szakértelmet, anyagi támogatást ad, és még számos más téren is segítséget nyújt, amelyet, ha a tagállamok megfelelően igénybe vesznek,

\footnotetext{
Hegyaljai Mátyás: Az EMPACT mint rendészeti válasz az európai bünözésre. Pécsi Határör Tudományos Közlemények, 15. (2014), 131-132.

6 Serious and Organized Crime Threat Assessment.

7 Europol: EU Serious and Organised Crime Threat Assessment (SOCTA 2013). Report. 2013.

8 Boda (szerk.) (2019) i. m. 171.
} 
és felismerik az Europol által kínált lehetőségeket, máris hatékonyabb nyomozásokat végezhetnek. Fontos megemlíteni az Europol által kezdeményezett és irányított SIENA ${ }^{9}$ levelező rendszert, amely az egyik lehető leggyorsabb útja az információcserének jelenleg az EU tagállamai között. A levelezőrendszer már minden tagállamban jelen van, azonban mint például Magyarországon is, folyamatban van a minél több végpont létrehozása a még hatékonyabb információáramlás érdekében. A fent leírt valamennyi szempontra tekintettel kutatásom kezdetén elhatároztam, hogy ahhoz, hogy az Európai Unión belüli kábítószerhelyzetről egy átfogó képet kapjak, az Europol szerepét elengedhetetlen vizsgálni, hiszen valamennyi tagállam kábítószerhelyzetéről rendelkeznek információval. Felkeltette az érdeklődésemet, hogy az ott dolgozó munkatársak hogyan vélekednek a hivatalról, valamint mit gondolnak a tagállamok Europolnál betöltött szerepéről. Tekintettel arra, hogy nagyobb populációban kívántam a kutatást végezni, így azt a kvantitatív kutatási módszert választottam, amely által széles körű, viszonylag rövid időn belüli eredményeket kapok. Az Europolnál végzett angol nyelvú strukturált kérdőíves kutatás során többek között pontosan arra kerestem a választ, hogy az ott dolgozó személyek hogyan vélekednek egyrészt a tagállamok közötti információcseréről, valamint az együttműködésükről. Így hat kérdést fogalmaztam meg arra vonatkozóan, hogy mennyire látják hatékonynak a búnüldöző szervek küzdelmét a kábítószer-búnözés ellen, megfelelőek-e az EU-s jogszabályok, milyennek értékelik a munkájukat, mit gondolnak a továbbképzésekről nemzetközi szinten, milyen állást foglalnak a szabad mozgás kérdésében, valamint van-e arra lehetőség, illetve hogyan lehetne felgyorsítani az egyes nyomozásokban az ítélet meghozatalát. A kérdőívek elektronikus formában történő kitöltését megelőzően, célom volt, hogy az Europolnál különböző területeken dolgozó személyek töltsék ki azt. Így a kitöltők között szerepeltek kábítószer-specialisták, a különböző országokban dolgozó összekötő irodák munkatársai, valamint bűnügyi elemzők. A kapott válaszok tükrében megfogalmazható, hogy bár eltérő területeken dolgoznak, de hatékonynak értékelik munkájukat, azonban úgy vélik, hogy eredményes munkát akkor tudnak elérni, ha ahhoz a tagállamok is hasonlóképpen viszonyulnak. Néhány vélemény szerint egy decentralizált rendszerben (például Spanyolország, Belgium) sokkal hatékonyabb a nyomozás, mivel lehetőség van egymás felügyeletére, segítésére. Az európai uniós jogszabályokkal kapcsolatban nagyrészt ugyanazon a véleményen voltak, miszerint a jogszabályok harmonizációjának a növelésére a tagállamok között szükség lenne. A nyelvtudással kapcsolatban a legtöbben kiemelték, hogy az angol nyelv elengedhetetlen, de észrevették, hogy a legtöbb tagállam tolmács segítségét veszi igénybe a kommunikációhoz, ami nem a legmegfelelőbb, ha speciális, leplezett eszközöket alkalmazó nyomozásról van szó, hiszen egy speciális szakmai ismeretanyaggal nem rendelkező civil személy bevonása számos egyéb kérdést vethet fel bennünk. A speciális nyomozási tevékenységek európai uniós szabályozására nem térek ki, mivel azokat

Secure Information Exchange Network Application - Az Europol biztonságos információcserét kiszolgáló hálózata. 
már más szakmai publikáció részletesen feldolgozta, értékelte. ${ }^{10} \mathrm{~A}$ szabad mozgás gyakorlása esetében elmondták, hogy ez az elkövetők számára mindenképp nagy előnyt jelent, ami viszont a nyomozó hatóságok számára a legtöbb esetben hátrányt. Az ítéletek felgyorsítására tett javaslatok között szerepelt, hogy az egységes büntetési tételek megállapítása a tagországokban nagyban meggyorsíthatná ezt a folyamatot. ${ }^{11}$ Az elvégzett kérdőíves kutatást követően személyesen is eltöltöttem az Europol hágai székházában egy hetet, ahol tapasztalhattam, hogy mennyire koncentrált, komplex munka folyik annak érdekében, hogy a tagállamokat segítsék.

A hazai rendvédelmi szervek képviseletében az Europol Magyar Összekötő Iroda munkatársainak tevékenységébe is bepillantást nyertem. A legfontosabb következtetés számomra az volt, az ott töltött időszakot követően, hogy nem kizárólag Magyarországnak, hanem valamennyi tagállamnak, sőt egyéb államoknak, például az Amerikai Egyesült Államoknak és Ukrajnának is van összekötő irodája, ahol az összekötő tisztek az országuk érdekeit képviselik, és a közvetlen, személyes információcserét is biztosítják a képviselettel rendelkező országok között, ha esetleg azonnali információra van szükség, ami nagyban növeli a hatékonyságot. Összefoglalva elmondhatjuk, hogy az Europol szerepe lényeges a kábítószeres bűncselekmények felderítése, nyomozása során, ha már csak arra gondolunk, hogy a SIENA rendszeren keresztül, más tagállamoktól egy-egy személyre, gépjárműre vonatkozóan kapunk adatot, és ezzel lehetőség nyílik a nyers, elsődleges információkat megerősíteni vagy kizárni. Fontos, hogy a tagállamoknak nyitottaknak kell lenni a kínált lehetőségek felé, valamint más tagállamok felé is, hiszen az együttműködés csak így jöhet létre.

\subsection{Interjúk Ausztriában}

Még a pandémiás helyzetet megelőzően végeztem el a kutatásom részét képező kvalitatív kutatást, amelynek keretében interjúk felvételére került sor Ausztriában, Bécsben. Kutatási módszerem megválasztásának hátterében az állt, hogy mélyebb ismeretekre volt szükségem, az ok-okozati viszonyokat kívántam feltárni, azaz a „miértekre" kerestem a választ, eltekintve a saját személyes véleményemtől, álláspontomtól. Az itt töltött időszakban nemcsak a kutatáshoz szükséges interjúk elkészítését végeztem el, de a nyomozó kollégák mindennapi munkájába is betekintést kaptam. Interjúalanyaim voltak az Osztrák Szövetségi Bünügyi Hivatal vezetője, az ott dolgozó felderítők, az Europol Nemzeti Egység/Iroda (Europol National Unit), vezetője és két társa, továbbá az Interpol Iroda vezetője, valamint a Kábítószer Egység egyik szakértője. Az interjúalanyaim kiválasztásának, valamint a bécsi helyszín hátterében az áll, hogy a kutatást megelőző szakirodalmak tanulmányozása során tapasztaltam, hogy Magyarországgal számos párhuzam, de ellentét is megfigyelhető a két ország drog-

\footnotetext{
10 Nyeste Péter: Speciális nyomozási tevékenységek az Európai Unió tagállamaiban. Belügyi Szemle, 64. (2016), 3. 16-43.

11 Nagy Ivett: Kábítószer-bű́ncselekmények nemzetközi kitekintésben. Nemzetbiztonsági Szemle, 8. (2020), 2. 47-48.
} 
politikáját, valamint a nyomozó hatóságok tevékenységét illetően. Tudomásom volt továbbá arról is, hogy Bécsben található az amerikai Kábítószer-ellenes Hivatal (DEA) egy külföldi hivatala, és az ott dolgozó ügynökök gyakori látogatást tesznek a magyar nyomozó hatóságoknál információcsere végett. Ennek a hátterét kívántam felkutatni, ezzel együtt a hivatal múködését akartam megismerni. A bécsi látogatásom oka abban rejlik még, hogy szintén Bécsben található az ENSZ Kábítószer-ellenőrzési és Bűnmegelőzési Hivatala, amelyről a kutatás kezdetén olyan információkat gyűjtöttem, amelyek pontosabb megismerése hozzájárulhat a kutatási eredményhez.

Itt egy rövid kitekintés keretében egy olyan példát mutatok be, amely számomra meglepő volt, hiszen Ausztria és Magyarország földrajzi közelségéből adódóan nem számítottam erre. A kábítószerrel kapcsolatos példát azonban nem a kereskedői oldalról, hanem a fogyasztói oldalról közelítem meg. Az örök dilemma talán ott van minden ország (ahol nem beszélhetünk legalizációról) drogpolitikájában, hogy a kábítószer legalizálása, vagy bizonyos mértékű legalizálása a rendőrség számára könynyebbséget vagy még nagyobb terhet jelent. Kérdésként merült fel bennem, hogy öszszehasonlítható-e a két ország drogpolitikája, hatékonyabb nyomozást végeznek-e az osztrák kollégák, vagy a hazai gyakorlat hatékonyabb. A bécsi kollégáknál töltött időszakban vált számomra nyilvánvalóvá, hogy többek között Bécsben is találhatók olyan boltok, amelyek más nyugat-európai országokban is jelen vannak már. Ezekben például kendermagpalánták, kendermagok, és más kenderrel kapcsolatos élelmiszerek, italok és egyéb termékek vásárolhatók meg. A boltban, a falon jól láthatóan szerepel a „Hogyan termesszünk kendert házilag?” felirat. Kapható itt bongo is, ami hasonló a vízipipához, ebből szippantani lehet a kenderszármazékot. Tehát a boltban megvásárolható valamennyi termék legális, de például palántákból tilos kábítószert előállítani. A Bushplanet Headshop egy tipikusan ilyen bolt, amit a cannabisbirodalom központjának is neveznek, a bolt tulajdonosa a cannabis legalizálásáért küzd évek óta, de világviszonylatban Ausztria félúton van a cannabis legalizálása terén. Ausztriában a cannabis kis mennyiségű, saját célú felhasználását továbbra sem büntetik, annak kereskedelme viszont már nem engedélyezett. Bécsben cannabisautomatát helyeztek ki a főváros egyik leghíresebb utcáján. A cannabis hatóanya kevesebb mint 0,3\%-ban található meg az itt vásárolható termékekben, így az legális. A fentiekről egy cikkben olvastam, ami úgy végződik: „Mit szólnátok, ha a Váci utcán is állítanának egy ilyet?"12 Azaz folyamatosan megjelenik az emberek gondolataiban a mi lenne, ha hazánkban is lenne erre lehetőség. Az elmúlt években a kábítószer legalizálását sokkal távolabbinak gondoltuk, hiszen például Hollandia földrajzi távolsága, kábítószer-politikája, liberális felfogása miatt is idegen számunkra. Ausztria viszont már valóban félúton van a legalizálás felé. A fentieken túl viszont az osztrák nyomozókkal készített interjúk során ez a fajta „fél” legalizálás még inkább kihívás elé állította őket. Úgy gondolják, hogy ezzel csak a kábítószer-kereskedelem még nagyobb melegágyát alapozták meg a jogalkotók, hiszen a lakásoknál történő árusítástól kez-

12 Stadtmüller Viktor: Kannabisz automaták Bécsben, legálisan. Így lehetséges. 2018. 
dődően az utcai dílerek száma egyaránt nőtt az elmúlt években. Gondoljunk csak bele, hogy ha a másik szemszögből is megfigyeljük a jelenséget, a kábítószer árát csak növeli az a tényező, hogy ahhoz illegálisan jutnak hozzá, benne van minden kockázati tényező, amivel számolnak egy-egy adag árának meghatározásakor. Kérdésemre elmondták, hogy mivel már egy olyan úton indultak el, amely a kábítószer teljes körú legalizálásához vezet, ellenkező irányba nem valószínú, hogy ez a folyamat haladni fog, így a hatóságok számára a legnagyobb könnyebbség lenne az, ha azt teljeskörǔen legalizálnák, igazodva a jogszabályi feltételekhez.

Magyarország tekintetében a fogyasztás ugyanúgy büntetett cselekmény, de vajon valaha felmerül-e az a kérdés, hogy de meddig? Németh Zsolt kriminológus szerint „a fogyasztót fenyegetéssel és büntetéssel nem lehet távol tartani a veszélyes anyagtól”, valamint szerinte „a fogyasztóval szembeni bűnüldözési aktivitás csupán pótcselekvés". Ezzel a kijelentésével egyet kell értenem, hiszen egy fogyasztót, aki már szerfüggő, nagyon nehéz arról meggyőzni, hogy már a szervezetére is milyen káros hatással van a kábítószer. A jelenleg hatályos jogszabályok tükrében a fogyasztókkal szembeni fellépés, büntetések kiszabása nem fogja távol tartani a kábítószer-fogyasztókat az egészségükre is káros tevékenységtől. Úgy vélem, közeledünk ahhoz az időponthoz, hogy a rendőrség mint általános bűnüldözési hatóság és jogalkalmazó szerv véleményét, javaslatait is figyelembe kell venni, amikor az érintett jogszabályok, stratégiai tervek megalkotására, módosításokra kerül a sor.

A fent leírtakon túl megfigyelhető volt az interjúalanyok eltérő gondolkodása, annak függvényében, hogy ki hol dolgozik. Például az Europol és az Interpol Irodánál dolgozók egy nagyon pozitív képet tártak elém, tekintve az anyagi támogatásokat, a segítségnyújtást. A SIENA rendszerrel kapcsolatban annak hasznosságát hangsúlyozták és kiemelték, hogy egyes bűncselekmények esetében, ilyen a kábítószer-bűncselekmény is, milyen hatékonyan tudnak alkalmazni. Ezzel ellentétben amikor az osztrák felderítőket ugyanerről kérdeztem, akkor azt lassúnak és vontatottnak nevezték, és elmondták, hogy több SIENA végpontra lenne szükségük.

A kábítószeres felderítők inkább kedvelik a személyes kapcsolatok által beszerzett gyors információkat, példaként a magyar felderítőkkel való jó kapcsolatot említették, ahol elegendő egy telefonhívás, és megszerzik a szükséges információt. Felmerült a kérdés az interjú során, hogy az így szerzett információ bizonyító erôvel bír-e, felhasználható-e a nyomozás során, amire azt a választ kaptam, hogy igen. A felderítők elmondták, hogy az ügyészekkel jó kapcsolatot ápolnak, hiszen az is egyfajta együttmúködésnek tekinthető. Kiemelték, hogy egyes nyomozó hatóságok már úgy dolgoznak náluk, hogy egy épületben vannak az ügyészekkel, ezzel nagyon sok időt takarítanak meg, és a papírmunka is kevesebb. Kérdést intéztem a kábítószer-specialista felé, valamint a kábítószeres felderítők felé is, hogy mit gondolnak, melyik országgal a legkevésbé jó az együttmúködés. Erre úgy válaszoltak, hogy Horvátországgal a legkevésbé eredményes, Németországgal kifejezetten jó, de Magyarországgal, Olaszországgal, valamint Szerbiával is hatékony a munkakapcsolat. A kábítószerhelyzet jelenlegi kialakulására vonatkozóan úgy nyilatkoztak, hogy már jellemzően 
Ausztriából Magyarországra történik a kábítószer csempészése, nem pedig fordítva. Úgy fogalmaztak, hogy Ausztria egy közép-európai „kábítószer központtá vált”, aminek az oka talán Ausztria földrajzi elhelyezkedése, mert innen elérhető a legtöbb közép-európai ország. Elmondták, hogy a Balkán útvonalon érkező kábítószer-szállítmányok csökkentek, inkább Dél-Amerikából, repülőgépekkel érkeznek. Ennek köszönhetően az ország egyes repterein dolgozó hivatásos személyek folyamatos képzéseken vesznek részt, hogy ezeket a szállítmányokat sikerüljön kiszűrni. Több interjúalany kiemelte, hogy az EMPACT találkozók nagyon hatékonyak. Következtetésképp elmondható, hogy Ausztria kábítószer-fenyegetettsége jelentősebb, mint Magyarországé. A kábítószer-bűncselekmények kapcsán említették az egyik interjúban, hogy ez a fenyegetettség a 2015-ben lezajlott migránsáradat következménye, mivel a bevándorlók egy része Ausztriában, Bécsben telepedett le, majd őket követték a családtagjaik, és egy részükkel a Balkán útvonalon a kábítószer is érkezett.

\subsection{Drug Enforcement Administration}

ADEA (Drug Enforcement Administration), azazaz Amerikai Egyesült Államok Kábítószer-ellenes Hivatalának célja, hogy a kábítószer-csempészetet, valamint a terjesztést megállítsák. Összesen 91 külföldi hivatallal rendelkeznek a világon. Küldetésükként tekinthető, hogy az egész világon érvényesüljenek, a nemzetközi kábítószerpiacokon csökkenést érjenek el, azáltal, hogy felveszik a harcot a kábítószer gyártása, forgalmazása ellen is. ${ }^{13} \mathrm{~A}$ hivatal szerepe több szempontból is lényeges a kutatás során. Egyrészt, mivel Bécsben található, így sikerült személyesen találkoznom és interjút készítenem két ügynökkel, a másik pedig, hogy egy amerikai hivatal álláspontját is megvizsgálhattam. Kérdéseim között szerepelt, hogy miért épp Bécsben található hivataluk, amelyre azt a választ kaptam, hogy földrajzilag a közép-európai országok központjának tartják. Kérdéseim között szerepelt továbbá, hogy mi a véleményük a tagállamokkal történő közös együttműködésről. Megfogalmazták, hogy az információcsere hatékony, ám amikor a DEA-től kapott információt meg kellene osztani az egyik tagállamnak egy másikkal, akkor azt az információt inkább megtartják maguknak az országok, bízva abban, hogy a nyomozásuk ezáltal eredményesebb lehet. Hangsúlyozták a korrupció jelenségét, ami leginkább Koszovóban és Szerbiában jelent nagy problémát, ezekből az országokból az információáramlás nehezített. Azt tapasztalták, hogy a kelet-európai posztkommunista országok az együttműködésre kevésbé hajlandóak, nem nyitottak. A DEA kizárólag a kábítószeres bűncselekmények kapcsán tud az információcserében segítséget nyújtani a tagállamoknak. Interjúkészítésemnek hátterében, mint fentebb említettem, az is állt, hogy gyakran tesznek személyes látogatást a DEA ügynökök hazánkba információcsere végett. Ennek okaként az interjúalanyok úgy reagáltak, hogy a magyar nyomozó hatóságokkal jó kapcsolatot ápolnak,

13 United States Drug Enforcement Administration: Mission Statement. 
és úgy vélik, hogy a személyes találkozások során megosztott információk a leginkább hasznosíthatóak, hozzátették, hogy a Magyarországon tevékenységet ellátó FBI ügynökökkel (a továbbiakban erről bővebben) így személyesen is találkozhatnak, ezáltal még hatékonyabban tudják képviselni az Amerikai Egyesült Államokat.

\subsection{Egyesült Nemzetek Szervezete Kábítószer-ellenörzési és Búnmegelözési Hivatala (UNODC) ${ }^{14}$}

Felmerülhet a kérdés, hogy miért pont az ENSZ, és hogyan hozható kapcsolatba a kábítószer-bűncselekményekkel, milyen szerepet vállal az ENSZ a kábítószer-bűnözés elleni küzdelemben. Ezek azok a kérdések, amelyek bennem is megfogalmazódottak akkor, amikor bécsi látogatásom során az ENSZ Bécsi Nemzetközi Központjába, azaz az UNO Citybe, ENSZ városba látogattam. Az interjú során arra kaptam választ - mint ahogyan a hivatal nevében is szerepel „bűnmegelőzés” -, jellemzően ezt a tevékenységi kört látja el a hivatal. Az ENSZ Kábítószer-ellenőrzési és Bűnmegelőzési Hivatala globális hálózatokon keresztül segíti a tagállamokat (193 tagállam), hogy „fellépjenek a kábítószerek, a bűnözés, a korrupció és terrorizmus által okozott veszélyek ellen, valamint azon dolgozik, hogy előmozdítsa a biztonságot és az igazságosságot mindenki számára”. ${ }^{15}$ A Hivatalon belül múködő különböző részlegek szintén az államokkal való folyamatos kapcsolattartást segítik elő. Az interjúk során megállapítottam, hogy a hivatal csak kutatói munkát végez, valamint az országok statisztikai adatait gyújti össze és azokat elemzi-értékeli, majd az így kapott végtermékből kívánnak a bűnmegelőzésben szerepet vállalni. Hazánk, mint ahogyan a többi ország is, nagyban segíti a Hivatal munkáját, de ugyanez igaz visszafelé is, hiszen a magyar kábítószer-ellenes jogszabályok előkészítésében az UNODC nagy segítséget vállalt. Arra törekszik mindkét fél, hogy a folyamatos párbeszédet fenntartsák, és az UNODC által megállapított ismereteket a hazánkban folytatott gyakorlat jobbítására felhasználják az arra igényt tartó nyomozó hatóságok, hivatalok, szervezetek. ${ }^{16}$

A fent bemutatott célcsoportok egyéneivel készített interjúk eredményeként elmondható, hogy az osztrák nyomozó hatóságok munkája gördülékenyebb, illetve hatékonyabb, ha megfelelő szintű és mélységű az együttműködés az ügyészséggel, illetve, ha a bürokrácia kevésbé van jelen a nyomozások során. Az is megállapítást nyert többek között, hogy Bécs földrajzi elhelyezkedése miatt nem élveznek nagyobb előnyt a nyomozó hatóságok az egyes hivataloknál, mint a környező, más tagállamok hatóságai. Kutatási eredményként említendő továbbá az a megállapítás is, hogy az egyes hivataloknál - mint Europol, Interpol, DEA - dolgozó személyek kevésbé látják át a bűnüldöző hatóságok munkáját, így nem találkozik a hatóságok „kereslete” (a le-

14 United Nations Office on Drugs and Crime.

15 Az Egyesült Nemzetek Bécsben: www.unis.unvienna.org/unis/hu/unvienna.html

16 ENSZ Szervezetek Bécsben: ENSZ Kábitószer-ellenôrzési és Bünmegelózési Hivatala - United Nations Office on Drugs and Crime. 
hetséges együttműködésre az országokkal), a hivatalok által kínált lehetőségekkel. Ezáltal maradnak olyan platformok, amelyeket nem vesznek igénybe a bécsi nyomozók, holott arra minden opció adott.

\subsection{Federal Bureau of Investigation}

Az FBI (Federal Bureau of Investigation), azaz a Szövetségi Nyomozó Iroda ügynökeinek magyarországi jelenléte szintén felkeltette az érdeklődésemet. Az FBI honlapján szerepel mottóként, hogy: „Crime and terror have gone global. And so have we.” Ami anynyit jelent, hogy: „A bűnözés és a terror globálissá válik. És így mi is.”17 Magyarország Kormánya és az Amerikai Egyesült Államok kormánya által 2000-ben létrehozott, úgynevezett Egyetértési Nyilatkozatban határozták meg az együttműködés alapjait. Az Egyetértési Nyilatkozat megfogalmazza az információcserét a két ország között:

„1. információt cserélnek annak érdekében, hogy segítséget nyújtsanak egymásnak a nemzetközi méreteket öltő bűncselekmények megelőzésében, felderítésében, visszaszorításában és nyomozásában, valamint más, ezekhez kapcsolódó határon átnyúló cselekményekben;

2. a jelen Nyilatkozatot a vonatkozó belső jogszabályaikkal, valamint nemzetközi kötelezettségeikkel összhangban hajtják végre, különös tekintettel arra, hogy a másik Kormánytól kapott információ felhasználását csak olyan mértékben korlátozzák, ahogy arról a kölcsönös bünügyi jogsegély szerződés 7. Cikke rendelkezik, valamint megfelelően figyelembe veszik egymás belső jogszabályait és nemzetközi kötelezettségeit;

3. tájékoztatják egymást a lényeges belső jogszabályaikról és az azokban bekövetkező jövőbeni változásokról."18

Egy általam szervezett kerekasztal-beszélgetésen részt vett egy hazánkban itt tartózkodó ügynök, aki arról mesélt, hogy mennyire fontos az információcsere, és hogyan tud igazán hatékony lenni. Elmondta, hogy kezdetben Magyarország Oroszországhoz való földrajzi közelsége miatt kezdeményezték leginkább az együttműködést. Jellemzően amerikai érintettségű ügyekben vesznek részt, de előfordul, hogy technikai eszközökkel vagy más szakmai tudással támogatják a hazai nyomozó hatóságokat. Kiemelte, hogy mivel a magyar nyomozók és az ügynökök egy irodában belül végzik a tevékenységüket, még gyorsabb az információcsere. Számukra fontos, hogy ez az együttműködés megmaradjon a továbbiakban is.

Federal Bureau of Investigation: Crime and terror have gone global. And so have we. FBI.

36/2000. (III. 17.) Korm. rendelet a Magyar Köztársaság és az Amerikai Egyesült Államok Kormánya között a szervezett bünözés megelőzésére és visszaszorítására vonatkozó információk cseréjéről. 
Érdekességként jegyzem meg, hogy Budapesten, a hazánk és az USA kormánya között 1996-ban megkötött megállapodás ${ }^{19}$ alapján, Nemzetközi Rendészeti Akadémia (International Law Enforcement Academy - ILEA) ${ }^{20}$ működik. A nemzetközi hálózat részeként múködő Akadémiát az amerikai fél által kinevezett amerikai igazgató vezeti, aki az USA Igazságügyi Minisztériuma Szövetségi Nyomozó Irodájának kiemelt különleges ügynöke, míg helyettese az USA Külügyminisztériuma Diplomáciai Biztonsági Szolgálatának (Diplomatic Security Service - DSS) kiemelt különleges ügynöke, aki ugyancsak jogi attasé szintű diplomata. Az ILEA feladata, hogy továbbképzési lehetőséget biztosítson a kelet-közép-európai országokban, valamint a volt Szovjetunió utódállamaiban szervezett bűnözéssel foglalkozó, rendészeti középvezetői beosztást betöltő szakemberek részére, továbbá segítséget nyújtson a térség újonnan demokratizálódó államainak a nemzetközi szervezett bűnözés elleni harc és a bűnüldözői munka terén jelentkező feladatok magasabb szintű megoldásában. ${ }^{21}$

Az FBI Magyarországon betöltött mélyebb szerepét a későbbiekben vizsgálni kívánom, viszont a megrendezett kerekasztal-beszélgetés során nyert megállapítást, hogy az amerikai Szövetségi Nyomozó Iroda és a magyar hatóságok elmélyült, közös munkájára jelenleg is és a jövőben is nagy szükség lesz.

\section{4. Összegzés}

A kábítószer-bűnözés nemzetközi kutatása hosszú évekre feladatot tud adni. Úgy gondolom, hogy az eddig elvégzett kutatási módszerek által, és a fent leírt, kapott eredmények tükrében tovább szűkíthetem, konkretizálhatom az egyes területeket. Az eddig elvégzett kérdőíves kutatás és az elkészített interjúk által sikerült meghatároznom a kutatás következő területeit, illetve alanyait. Összességében elmondható a kérdőíves felmérés, valamint a készített interjúk tükrében is, hogy mind az Európai Unión belül, mind azon kívül egyre nagyobb hangsúlyt kell fektetni az együttmúködésre, és nyitottnak kell lenni, bátornak az új lehetőségek befogadására, közvetítésére. Megállapítást nyert továbbá az is, hogy az országok hozzáállása sok szempontból meghatározó egy nemzetközi bűnügyi együttműködésben, hisz, ha csak az Európai Unión belüli tagállamokat vesszük figyelembe, az Europolnál minden tagállam képviselteti magát, használhatják az Europol együttmúködési platformjait, csatornáit, a nyomozásokhoz hozzáadott szakértelmüket, de vajon ezt a lehetőséget kellően „kiaknázzák-e" a tagállamok. Az eddigi részeredmények tükrében viszont csupán részben, alacsony arányban veszik igénybe a rendelkezésre álló lehetőségeket. Ezt támasztják

19 A Magyar Köztársaság Kormánya és az USA Kormánya között az ILEA létesítéséről szóló Megállapodás [165/1996. (XI. 20.) Kormányrendelet], illetve az annak végrehajtására létrejött Megállapodás, valamint annak 1998. 12. 11-én és 2000. 09. 13-án hatályba lépett módosítása szerint múködnek együtt.

20 Az Akadémiáról bővebben: https://budapest.ilea.state.gov/

21 Lippai Zsolt: A Nemzetközi Oktatási Központ, a vele kapcsolatban álló nemzetközi szervezetek és az idegennyelvi képzés. In Czene-Polgár Viktória - Zsámbokiné Ficskovszky Ágnes (szerk.): Innováció, elektronizáció, tudásmenedzsment. Budapest, Magyar Rendészettudományi Társaság Vám- és Pénzügyőri Tagozat, 2018. 164-165. 
alá az Europol munkatársai részéről érkezett válaszok, valamint a bécsi nyomozó hatóságok véleménye. Az okok feltárása még folyamatban van. A személyes kapcsolatok, személyes találkozókon történő információszerzés mindegyik interjúalany esetében hangsúlyos volt, annak eredményessége nem vonható kétségbe. Példaként említhető, hogy egy közös nyomozó csoport létrehozásával a nemzetközi kábítószeres bűncselekmények felderítése, bizonyítása sokkal gördülékenyebbé tud válni, és a közvetlen együttműködés alapján a kommunikáció, információáramlás hatékonysága megtöbbszöröződhet. Azaz nem az a kérdés, hogy elegendő-e a rendelkezésre álló platform a kábítószer-búnözés elleni nemzetközi fellépésben, hanem hogy ezeket a felületeket hogyan lehetne még hatékonyabbá tenni, valamint hogy tovább bővíthetők-e ezek. Véleményem szerint a hatékonyabbá tételre egyértelműen van lehetőség, hiszen, ha arra gondolunk, hogy különböző nemzetközi fórumok megrendezésére gyakrabban kerülne sor (akár online felületen is), vagy ezeken a fórumokon valamennyi olyan ágazat képviseltetné magát, akik részt vesznek a kábítószer-bűncselekmények nyomozásában, az elkövető felelősségre vonásában, akkor már hatékonyabb lehet az együttmúködés. Az egyik legfontosabb, az eddigiek alapján, hogy ha az országon belüli hatóságok bűnügyi együttműködése nem kellően hatékony, kommunikációs akadályok is jelentkeznek, vagy a nyomozó hatóságok és az ügyészség munkája nem gördülékeny, akkor elsődlegesen a határon belüli együttműködésre kell a hangsúlyt fektetni.

\section{IRODALOMJEGYZÉK}

Boda József (szerk.): Rendészettudományi szaklexikon. Budapest, Dialóg Campus, 2019.

Hegyaljai Mátyás: Az EMPACT mint rendészeti válasz az európai bűnözésre. Pécsi Határőr Tudományos Közlemények, 15. (2014), 127-134.

Lippai Zsolt: A Nemzetközi Oktatási Központ, a vele kapcsolatban álló nemzetközi szervezetek és az idegennyelvi képzés. In Czene-Polgár Viktória - Zsámbokiné Ficskovszky Ágnes (szerk.): Innováció, elektronizáció, tudásmenedzsment. Budapest, Magyar Rendészettudományi Társaság Vám- és Pénzügyőri Tagozat, 2018. 163-186.

Nagy Ivett: Kábítószer-bűncselekmények nemzetközi kitekintésben. Nemzetbiztonsági Szemle, 8. (2020), 2. 40-49. Online: https://doi.org/10.32561/nsz.2020.2.3

Nyeste Péter: A bűnügyi hírszerzés. Magyar Rendészet, 12. (2012), 4. 25-31.

Nyeste Péter: Speciális nyomozási tevékenységek az Európai Unió tagállamaiban. Belügyi Szemle, 64. (2016), 3. 16-43. Online: https://doi.org/10.38146/BSZ.2016.3.2

\section{Jogi forrás}

36/2000. (III. 17.) Korm. rendelet a Magyar Köztársaság és az Amerikai Egyesült Államok Kormánya között a szervezett bủnözés megelőzésére és visszaszorítására vonatkozó információk cseréjéről 


\section{Internetes források}

ENSZ Szervezetek Bécsben: ENSZ Kábitószer-ellenőrzési és Bünmegelőzési Hivatala - United Nations Office on Drugs and Crime. Online: http://vienna.io.gov.hu/unodc-bemutato

Europol: EU Serious and Organised Crime Threat Assessment (SOCTA 2013). Report. 2013. Online: www.europol.europa.eu/activities-services/main-reports/eu-serious-and-organised-crime-threat-assessment-socta-2013

Federal Bureau of Investigation: Crime and terror have gone global. And so have we. FBI. Online: www. fbi.gov/contact-us/legal-attache-offices

Stadtmüller Viktor: Kannabisz automaták Bécsben, legálisan. Így lehetséges. 2018. Online: https:// noizz.hu/szines/cannabis-automatak-becsben/g4h8tdk

United States Drug Enforcement Administration (DEA): Mission Statement. Online: www.dea.gov/ mission

\section{ABSTRACT}

\section{Current Issues in Drug-related Crimes from an International Perspective} Ivett NAGY

An important feature of drug crime is that there are no victims of the crime, which makes the work of the authorities even more difficult. Investigating authorities in other Member States of the European Union also face this challenge, so I focused on the possibilities available to Member States to make their investigations effective. I focused on international cooperation, police information exchange, operational cooperation and on the fight against organised crime. In the course of my research, I conducted interviews with Austrian counterparts, researched the role of Europol (questionnaire research), and in the light of the results found so far, contacted US federal agencies and the United Nations Office on Drugs and Crime. With the established results, I intend to provide practical solutions that are relevant to the profession.

Keywords: drugs, drug crime, international investigation 